\title{
A WIGGLE-MATCHED DATE FOR THE COPPER AGE CEMETERY AT MANERBA DEL GARDA, NORTHERN ITALY
}

\author{
Lawrence H Barfield $^{1 \dagger}$ • Sturt W Manning $•$ Erio Valzolgher $^{3,4}$ • Thomas F G Higham ${ }^{5}$
}

ABSTRACT. The cemetery in the Riparo Valtenesi rockshelter at Manerba del Garda in northern Italy is well known for its wooden burial chambers. These chambers are some of the best sources of evidence for 3rd millennium BC collective burial in Europe. To further refine the absolute dating of burial activity at the site (beyond the approximate data provided by a previous series of routine radiocarbon measurements), a charred construction oak timber was sampled from Chamber 133 for ${ }^{14} \mathrm{C}$ dendro wiggle-matching (DWM). We present the results from the DWM analysis, the first of its kind for the Italian Copper Age as a whole, establishing a terminus post quem for construction of Chamber 133 2955-2872 cal BC.

\section{INTRODUCTION}

The Manerba cemetery occupies a natural rockshelter, the Riparo Valtenesi, some $60 \mathrm{~m}$ long and $90 \mathrm{~m}$ high, below the high cliff of the Sasso, at the southwestern end of Lake Garda in northern Italy $\left(45^{\circ} 33^{\prime} 21^{\prime \prime} \mathrm{N}, 10^{\circ} 34^{\prime} 41^{\prime \prime} \mathrm{E}\right.$; $70 \mathrm{~m}$ asl; see Figure 1). Excavations were carried out in the Riparo Valtenesi between 1976 and 1994 by the University of Birmingham (UK), under the direction of Lawrence H Barfield (in general, see Barfield 2007a). A total of $94 \mathrm{~m}^{2}$ was excavated, $52 \mathrm{~m}^{2}$ of which had been disturbed or destroyed by Roman-era (and later) limestone quarries. The intact deposits revealed the existence of a unique group of wooden collective burial chambers and several other funerary features dating to the early Italian Copper Age, as well as a deposit transitional between the Mesolithic and the Early Neolithic, traces of later Neolithic, mainly Lagozza, and Iron Age and Early Medieval activity. The sherds of at least 2 Beakers were found in unstratified contexts indicating some form of post-Copper Age activity as well. Other finds were made at Site B, less than $100 \mathrm{~m}$ north of the rockshelter on the lake edge. The preservation of the Copper Age burial areas appears to have been helped by the fact that the Roman quarryworkers deliberately avoided disturbing the burial deposits when operating their quarries. Some 6 chambers (Figure 2)-the Southern Chamber, the Burnt Burial Deposit N1-N3, and the 4 Northern Chambers (132, 133, 134, and 135) — produced a rich assemblage of beads, flint arrowheads, and decorated pottery. The pottery shows associations with material found in the Remedello di Sotto cemetery (Brescia) and other Italian sites.

In its Italian context, the Manerba site can be placed within the Civate group of Lombardy, one of the 3 areas or groupings of collective burial - mainly in caves (the grotticelle funerarie) - in northern Italy along with the Ligurian caves and the Vecchiano group of Tuscany (Barfield 1985, 1987, 1998). This northern Italian tradition of collective burial can, on a broader scale, be clearly located within the tradition of collective burial that flourished in northern and western Europe between the end of the 5th and the end of the 3rd millennia BC. While this phenomenon was mainly characterized by megalithic tombs, it also encompassed a range of wooden tombs, monumental earth and

\footnotetext{
${ }^{1}$ Institute of Archaeology and Antiquity, Arts Building, University of Birmingham, Edgbaston, Birmingham B15 2TT, United Kingdom. Sadly, Lawrence H Barfield passed away 2 July 2009.

${ }^{2}$ Department of Classics \& Malcolm and Carolyn Wiener Laboratory for Aegean and Near Eastern Dendrochronology, B-48 Goldwin Smith Hall, Cornell University, Ithaca, New York 14853-3201, USA.

${ }^{3}$ Ricerche Archeologiche snc/Archäologische Untersuchungen OHG, via Guglielmo Marconi/Guglielmo-Marconi-Strasse 8, I-39042 Bressanone/Brixen (Bolzano/Bozen), Italy.

${ }^{4}$ Corresponding author. Email: eriovalz@gmail.com.

${ }^{5}$ Oxford Radiocarbon Accelerator Unit, Research Laboratory for Archaeology and the History of Art, University of Oxford, Dyson Perrins Building, South Parks Road, Oxford OX1 3QY, United Kingdom.
}

(C) 2010 by the Arizona Board of Regents on behalf of the University of Arizona Proceedings of the 20th International Radiocarbon Conference, edited by A J T Jull RADIOCARBON, Vol 52, Nr 2-3, 2010, p 984-1001 


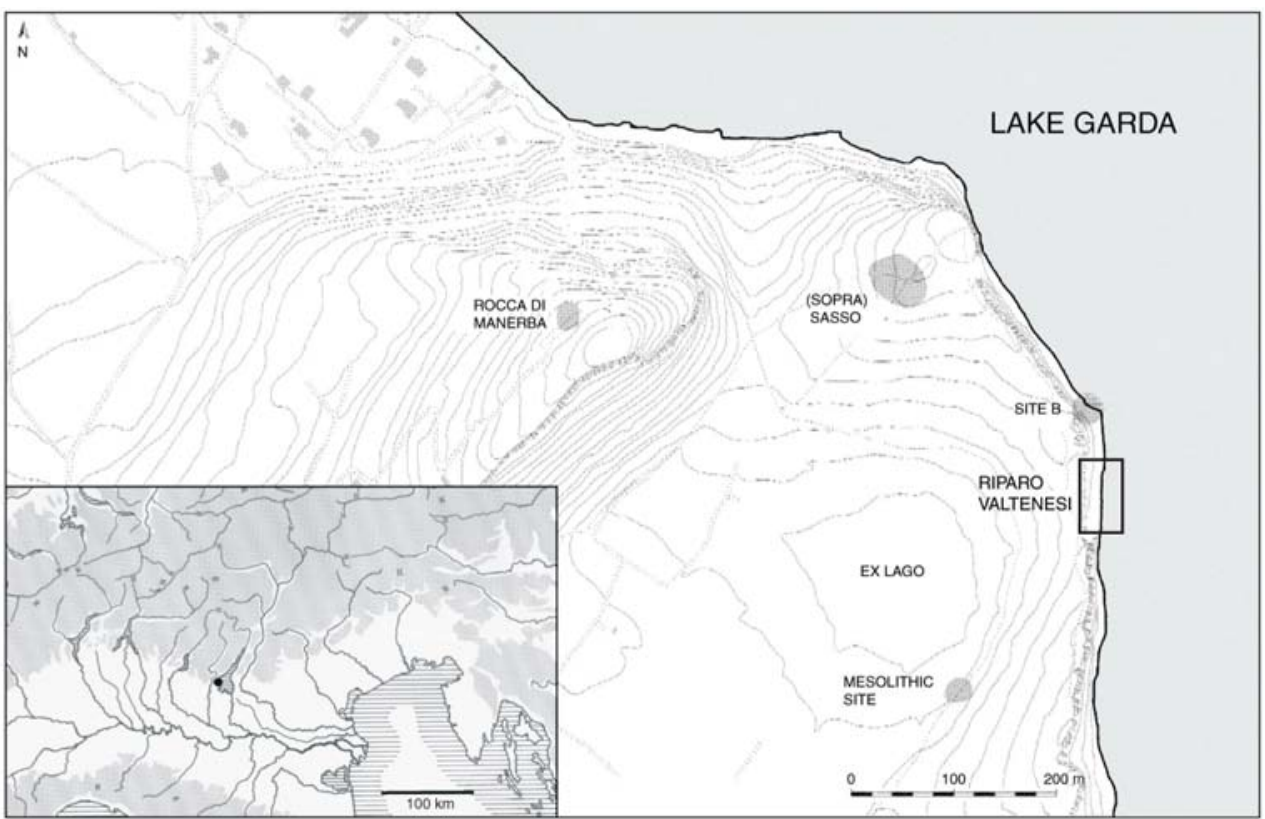

Figure 1 Map of the Manerba promontory showing the location of the Riparo Valtenesi rockshelter (modified after Barfield 2007a:12, Figure 2).

stone mounds, and rock-cut tombs, as well as cave and rockshelter burials. Wooden chambers and wooden elements associated with collective burial monuments are widely distributed throughout several areas of northern and western Europe where suitable stone for megalith construction was absent (Barfield 2004:46, 2007d:436-7 and references therein). Such was the case for the Manerba area, whose bedrock, belonging to the so-called "Formazione di Manerba," is made up of calcarenite, calcareous breccia, sandstone, and arenaceous limestone (Baroni 2007:507). Wooden chambers may therefore be seen as equivalent to megaliths built of wood, reflecting a choice determined by geological constraints.

The availability of a number of relatively well-preserved charred wooden structural elements in Chamber 133 enabled us to attempt a radiocarbon dendro wiggle-match (DWM) on one of these timbers (Timber F), as a continuation of the ${ }^{14} \mathrm{C}$ dating program undertaken at the site since the late 1970s/early 1980s (Barfield and Kuniholm 2007).

\section{BURIAL CHAMBER 133}

This burial structure, situated in the northern area of the rockshelter (Figure 3), consisted of a burial deposit on a stone-paved floor and the remains of surrounding burnt wooden structures. It was rectangular and had been set against the rock face directly parallel to Chamber 132 . The overall paved area with the wooden walls was approximately $1.95 \times 1.10 \mathrm{~m}$. Wooden structural elements lined almost the whole perimeter of the chamber. Six separate timbers surrounded the floor and 1 large fragment was found lying across it (Timber A). Along the southern side was a well-preserved charred, horizontal, squared beam (Timber B), $1 \mathrm{~m}$ long, $9 \mathrm{~cm}$ wide, and $1 \mathrm{~cm}$ high. Along the east and north sides, the timbers, by contrast, had been set vertically. On the eastern side, there were 2 timbers (C and D). Timber $C$ was at least $30 \mathrm{~cm}$ and Timber $\mathrm{D}$ was $20 \mathrm{~cm}$ wide. Timbers $\mathrm{C}$ and $\mathrm{D}$ were preserved to a total height of $8 \mathrm{~cm}$ and were slightly inclined toward the center of the chamber. 


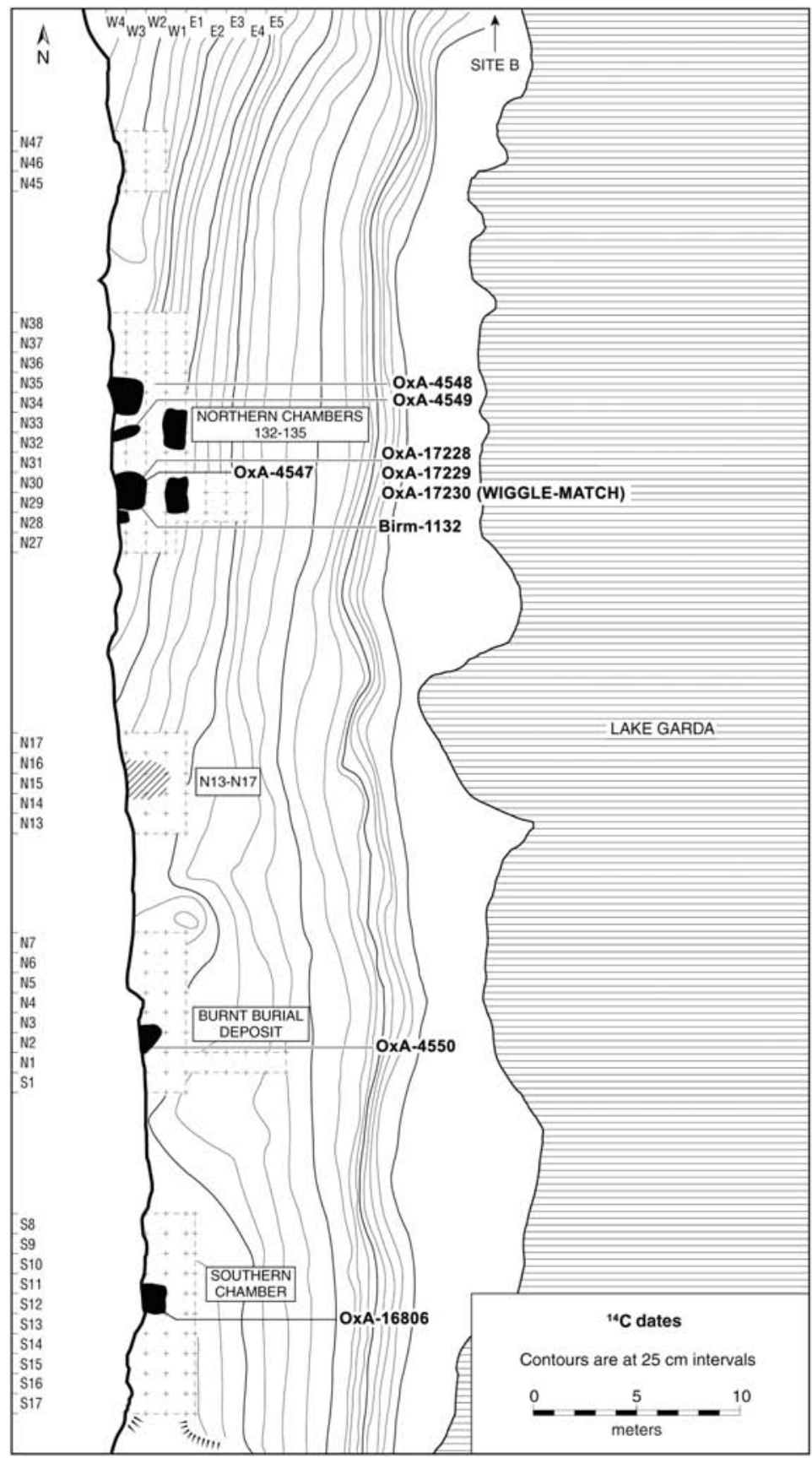

Figure 2 Plan of the overall Manerba funerary complex (Northern and Southern areas), indicating the locations of dated samples (modified after Barfield and Kuniholm 2007: 425, Figure 198).

Timber C was partially supported by a burnt, crushed human skull. On the northern side, there were at least 3 vertical timbers (E, F, and G). Timber $\mathrm{E}$ was $25 \mathrm{~cm}$ wide and made from a split tree trunk with the split side facing outward to the north. Timber F was at least $18-20 \mathrm{~cm}$ in diameter as found. 


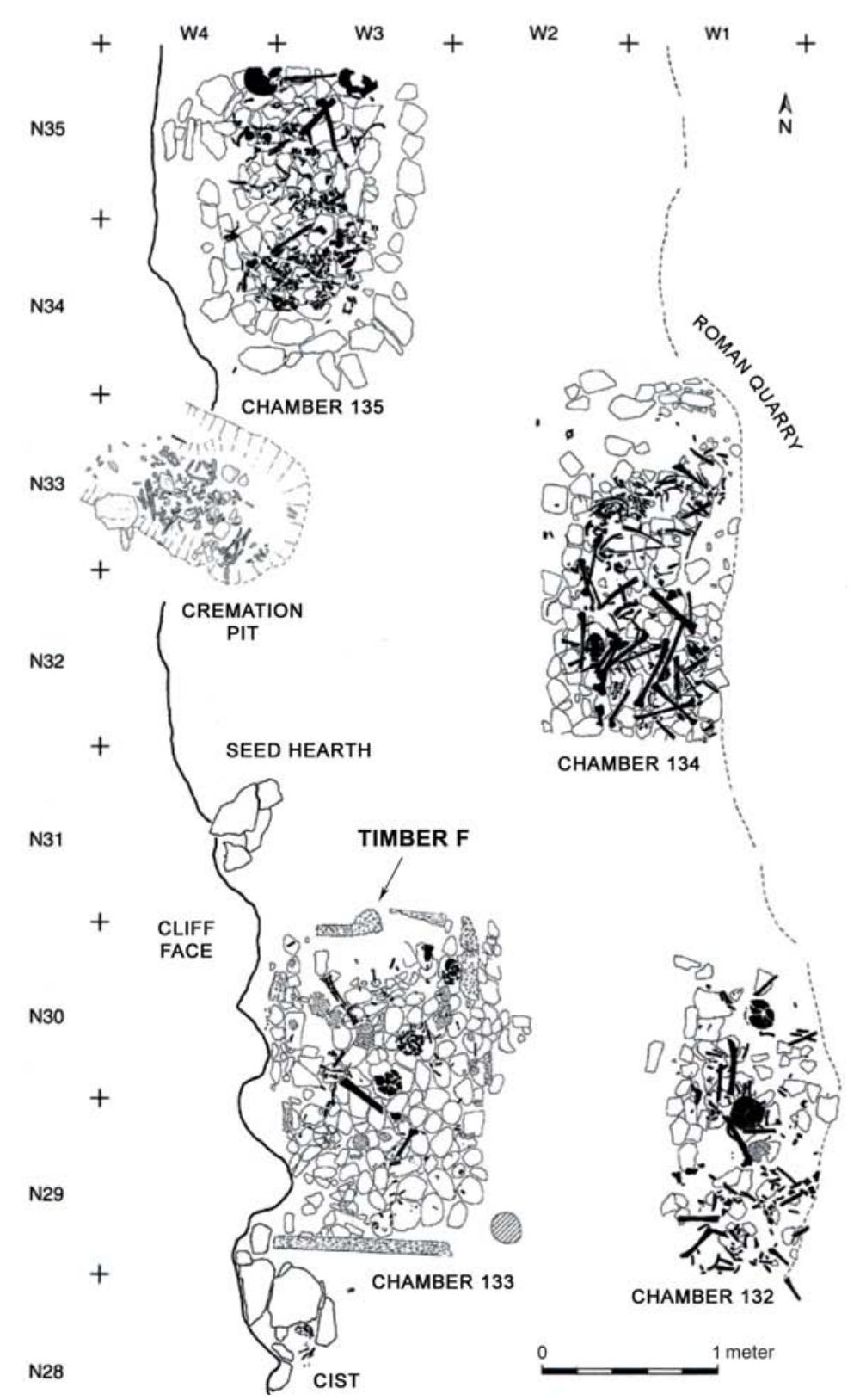

Figure 3 Plan of the Northern area of the Manerba funerary complex, indicating Chamber 133, from which Timber F was taken (modified after Barfield 2007b:64, Figure 34).

A maximum preserved height of $\sim 25 \mathrm{~cm}$ may be calculated for Timber F. Timber $\mathrm{G}$ had the best preserved cross-section, showing it to be a squared timber $22 \times 7 \mathrm{~cm}$, preserved to a height of $10 \mathrm{~cm}$. It had also been made from a split trunk, but in this case the split side was facing inward. (There are some discrepancies in the measurements of the timber elements when comparing earlier publications [Barfield 1982:11, 1983:118, 2004:39, 2007b:70]. We have made our best estimates from the plans and photographs. The timbers were mainly trunks split in half, and it would seem that in some cases the measurements were mistakenly doubled when stated [see Barfield 2007b:70]. In fact, how- 
ever, the whole diameter was likely present across the longitudinally split trunk, as evident in the plans and photographs.) In all cases, the wood could be identified as oak (Barfield 1983:118, 2004: 39). For 5 timbers (A, C, E, F, and G), however, a more precise identification of species was possible (most probably pedunculate oak-Quercus cf. robur L., sometimes called Q. pedunculata Ehrh.) (Nisbet and Barfield 2007:414-5, Table 29). Along the rock face on the west side the only carbonized timber was a small horizontal piece, measuring $20 \mathrm{~cm}$ across. It is impossible to say whether this had been part of a wall structure or some other fallen timber. The entrance to the chamber was probably either on the south side, or at the southern end of the east side. The roofing of the chamber was presumably thatched. The floor, made of beach pebbles and calcarenite fragments, was covered by a burnt organic deposit containing phytoliths from grasses (mainly Festucoideae) (Nisbet and Barfield 2007:417-8) and on the floor were scattered human bones and artifacts. The human bones were heavily burnt, though not calcined (Barbara Lippi, personal communication, 2009), and comprised a minimum of about 5 individuals ( 3 adult males, 1 adult female, and 1 unidentified individual), incomplete and disarticulated (Barfield et al. 2007:335, 345-6). The burial ritual at Manerba is reconstructed as essentially one of direct burial into the chambers with subsequent manipulation and removal of the bones. The burning of already defleshed human bones is evident in two of the Northern Chambers (133 and 135, respectively), although whether this was done intentionally rather than as an accidental byproduct of the burning of the wooden structures is not clear. (Dry human bones were, however, deliberately burnt in the Cremation Pit and probably in the Burnt Burial Deposit N1-N3.)

Artifacts comprised a series of potsherds, some belonging to individual vessels that had probably been placed originally in the chamber and subsequently broken and largely removed. A series of flint flakes, certainly from a single striking sequence (chaine opératoire), with some joins or refits possible, represented lithic work activity perhaps related to the preparation of tools used in the construction or maintenance of the chamber. A polished greenstone axehead was embedded in the floor. Several hundred beads, mainly of marble and steatite, probably representing at least 2 necklaces, were recovered. In places, these were still in their original alignment on the floor, in 1 case with copper necklace elements. Another sequence of beads still held a carbonized thread, which analysis showed to be of animal fiber (sinews) (Nisbet and Barfield 2007:418). Burnt seeds and Cornelian cherry (Cornus mas L.) stones were found in clusters in the chamber. At some time during its use, the chamber was filled with stones related to its closure and the construction of a covering platform (i.e. the Southern Platform), and set on fire. More artifacts were deposited at this time, including 4 complete pots and a flint strike-a-light. The burning of Chamber 133, which we see as deliberate, evidently took place at the time of its infilling and the construction of the Southern Platform, since the stones of this feature were heavily burnt. We suspect that the strike-a-light, in the upper levels of the fill, may have been related to the burning of the chamber.

\section{DENDRO WIGGLE-MATCH DATING OF TIMBER F}

\section{Materials and Methods}

The sample employed in this study (MAN-1), part of Timber F (a vertically placed trunk) from burial chamber 133, was received at the Cornell Tree-Ring Laboratory (December 1997) coated with plaster that compromised the sample. Specifically, the original outer rings (and any possibly originally present sapwood) had unfortunately deteriorated (dried out and lost physical integrity) and the sample had accordingly become a little smaller (extrapolated extant diameter on receipt was only around $17 \mathrm{~cm}$, versus about 18-20 cm on discovery [August 1981]), implying perhaps $\sim 1-3 \mathrm{~cm}$ of shrinkage and lost rings/sapwood. It is impossible to accurately estimate how many growth rings 
(yr) are thus lost, and whether, as might seem likely with no further information, it is just the sapwood that went missing or also some preceding heartwood rings. The sample comprises different pieces of the original (single) timber. These 11 pieces can be studied and fairly securely reassembled or refitted together as the one (original) Timber F sample and tree-ring record (except for the lost/ compromised outermost rings), and the rings measured to form an overall chronology of probably 79 rings (rings 1001-1079): see Figure 4. Some rings are hard to read and measure, and it is possible that 1 ring is counted twice where a few fragments join around rings 1039-1040, but this caveat has no substantive impact on the analyses below. This chronology does not currently cross-date against any other available tree-ring chronology, and its relatively short length, and rather erratic pattern, likely preclude a successful dendrochronological crossmatch dating in isolation. Therefore, to obtain a relatively precise approximate absolute date for the sample, we employed ${ }^{14} \mathrm{C}$ wiggle-match dating of the tree-ring series (Bronk Ramsey et al. 2001; Bayliss and Tyers 2004; Galimberti et al. 2004).

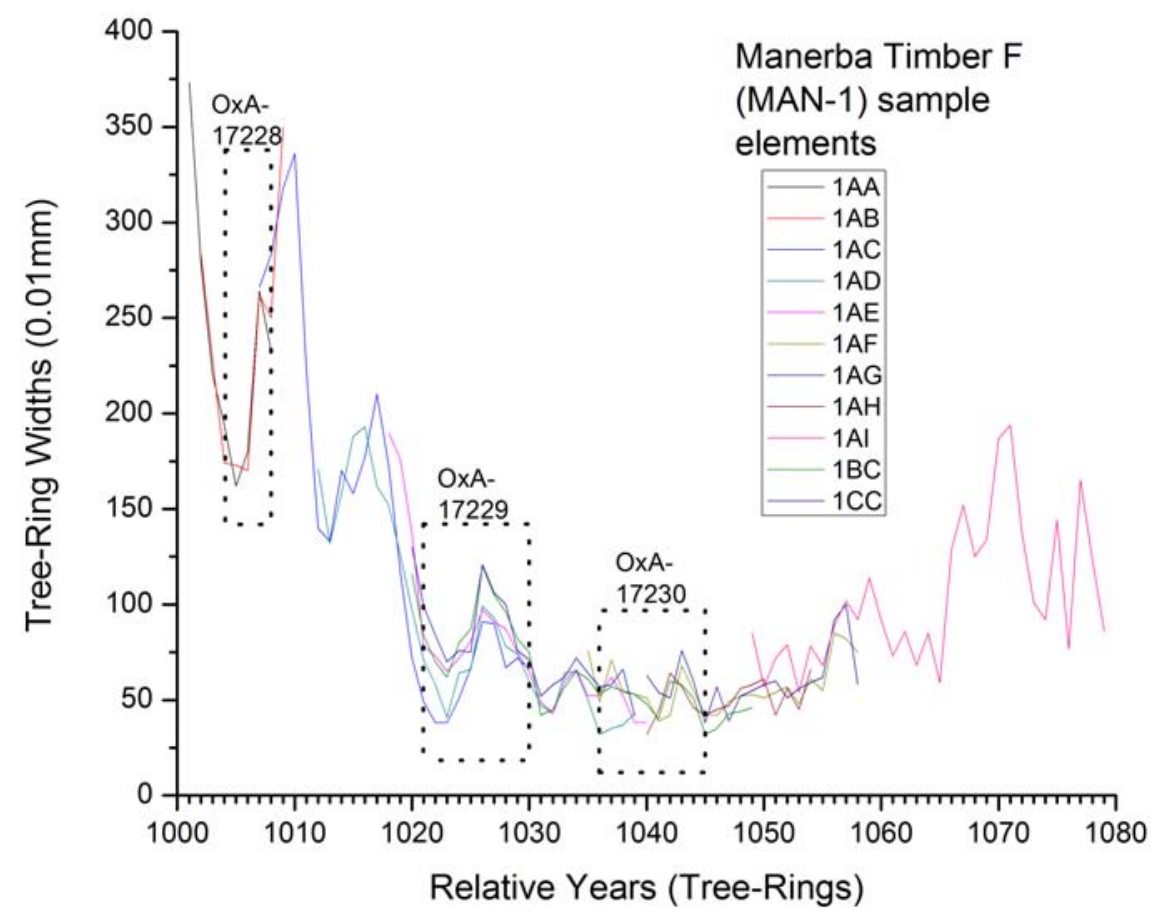

Figure 4 The 11 measured segments of tree rings comprising the single (as originally recovered) Timber F Quercus cf. robur L. sample (labeled MAN-1 at the Cornell Tree-Ring Laboratory) covering relative rings 1001-1079 (we follow a convention of numbering the tree rings on a new sample as starting at ring 1001), as measured and assembled for this ${ }^{14} \mathrm{C}$ wiggle-match study. Note: the 11 fragments are associated and fitted together and yield the tree-ring sequence shown on the basis of the physical refitting of the known single timber $(\mathrm{F})$ as excavated and (minus damage to outer rings) as received in the Cornell Tree-Ring Laboratory (and not from the matching of the tree-ring curves shown above). The 3 segments employed for the ${ }^{14} \mathrm{C}$ determinations (see Table 1 ) are indicated by the dotted boxes.

As mentioned above, the sample, as it could be studied after the damage from the plaster casing (mistakenly) used to consolidate and transport it from Italy to Cornell, lacked sapwood and an unknown number of other outer tree rings (i.e. there is no evidence that the last currently preserved tree ring necessarily marks the heartwood/sapwood boundary, although this might be assumed to be likely as a natural "breakage" point in the sample, or a ring close to this transition). The approximate 
amount of tree rings no longer physically intact, based on observation of the sample as received, and observations made when the sample was recovered, indicate that there is no reason to assume a large amount of wood missing (maybe $\sim 1 \mathrm{~cm}$ or a bit more: see above). Thus, we are missing the sapwood and some (unknown) number of tree rings. It seems likely the tree was relatively young, $<100 \mathrm{yr}$ old, and thus the number of sapwood rings was likely at the lower end of the possible range for Italian oak (since the number of sapwood rings in oak generally correlates with age: see e.g. Bayliss and Tyers 2004; Haneca et al. 2009: Table 1). We lack detailed data on the distribution profile of sapwood rings for Italian oak-in contrast to the detailed information for English oaks (Bayliss and Tyers 2004; Miles 2005). Therefore, the best we can do is consider the average number of sapwood rings in a population of 95 Italian oak trees of $13.23 \pm 6.06$ (median 15, range 5-38) from the work of Nicoletta Martinelli cited by Haneca et al. (2009: Table 1). A younger but not junior tree (e.g. $>79+$ minimum sapwood rings of $5=84 \mathrm{yr}$ old, and likely $<100 \mathrm{yr}$ old) probably lies at best in the average range, and might tend to be at the lower end (and the overall sapwood range usually offers a distribution skewed to the shorter end; see Bayliss and Tyers 2004: Figure 3), but, if we employ this average range (a normal distribution) and remember there may be some missing heartwood rings as slight compensation, we probably nonetheless will then have a fair estimate of the likely range of time when the tree was cut down.

\section{Radiocarbon Dating}

Three samples from MAN-1-MAN-1A (rings 1004-1008), MAN-1C (rings 1021-1030), and MAN-1D (rings 1036-1045) — were submitted in early 2007 to the Oxford Radiocarbon Accelerator Unit (ORAU) for accelerator mass spectrometry (AMS) ${ }^{14} \mathrm{C}$ measurement. Samples dated in Oxford were prepared with the standard acid-base-acid (ABA) protocol (Brock et al. 2010). This involves a $1 \mathrm{M} \mathrm{HCl}$ wash at $80^{\circ} \mathrm{C}$ (for $1 \mathrm{hr}$ ), a rinse with hot $0.1 \mathrm{M} \mathrm{NaOH}$ (for $1 \mathrm{hr}$ ), and a final $\mathrm{HCl}$ wash for the same length of time. Interspersed within each wash, the sample is rinsed to neutrality with Milli$\mathrm{Q}^{\mathrm{TM}}$ distilled water. The samples were dried, weighed, and AMS dated. All samples were weighed into precleaned tin capsules for combustion. The gas was analyzed using a Europa Scientific ANCA-MS system consisting of a 20-20 isotope ratio mass spectrometer interfaced to a Roboprep CHN sample converter unit operating in continuous-flow mode using an He carrier gas. Graphite was prepared by reduction of $\mathrm{CO}_{2}$ over an iron catalyst in an excess $\mathrm{H}_{2}$ atmosphere at $560{ }^{\circ} \mathrm{C}$ prior to AMS ${ }^{14} \mathrm{C}$ measurement (Dee and Bronk Ramsey 2000; Bronk Ramsey et al. 2004a). Table 1 lists the data obtained in this investigation.

Table 1 AMS ${ }^{14} \mathrm{C}$ measurements on charred Quercus cf. robur L. construction Timber F from Chamber 133 (sample MAN-1).

\begin{tabular}{llllllllll}
\hline Lab nr & $\begin{array}{l}\text { Sample } \\
\text { code }\end{array}$ & Relative yr & $\begin{array}{l}{ }^{14} \mathrm{C} \text { age } \\
(\mathrm{BP})\end{array}$ & $\begin{array}{l}\text { Wt. used } \\
\text { PCode }\end{array}$ & $\begin{array}{l}\text { Yield } \\
(\mathrm{mg})\end{array}$ & $\begin{array}{l}\text { \% } \\
(\mathrm{mg})\end{array}$ & $\begin{array}{l}\text { Yield } \\
\text { \% }\end{array}$ & $\mathrm{C}^{\mathrm{d}}$ & $\delta^{13} \mathrm{C}^{\mathrm{e}}$ \\
\hline OxA-17228 & MAN-1A & $\begin{array}{l}\text { RY1004-1008 } \\
\text { [Midpoint 1006] }\end{array}$ & $4359 \pm 32$ & $\mathrm{ZR}^{\mathrm{f}}$ & 65.21 & 58.62 & 89.9 & 70.8 & -24.98 \\
OxA-17229 & MAN-1C & $\begin{array}{l}\text { RY1021-1030 } \\
{[\text { Midpoint 1025.5] }}\end{array}$ & $4363 \pm 32$ & $\mathrm{ZR}$ & 54.01 & 50.88 & 94.2 & 70.7 & -24.91 \\
OxA-17230 & MAN-1D & $\begin{array}{l}\text { RY1036-1045 } \\
\text { [Midpoint 1040.5] }\end{array}$ & $4385 \pm 33$ & ZR & 40.33 & 36.31 & 90 & 69.5 & -24.49 \\
\hline
\end{tabular}

${ }^{a}$ Wt. used is the amount of material pretreated.

${ }^{b}$ The yield represents the weight after treatment in $\mathrm{mg}$.

c\% Yield = percentage yield of material resulting after the chemical pretreatment of the samples.

$\mathrm{d} \% \mathrm{C}=$ the carbon present in the combusted material.

eStable isotope ratios are expressed in \%o relative to VPDB (Coplen 1994) with a precision of $\pm 0.2-0.3 \%$.

${ }^{\mathrm{f}} \mathrm{ZR}=$ the code referring to the ABA treatment used at the ORAU (Brock et al. 2010). 


\section{RESULTS AND DISCUSSION}

The resultant ${ }^{14} \mathrm{C}$ ages were then fitted against the international ${ }^{14} \mathrm{C}$ calibration curve given the known tree-ring spacings for the samples using OxCal 4.1.5 (Bronk Ramsey 1995, 2001, 2009, 2010) and IntCal04 (Reimer et al. 2004) $)^{1}$ (the dendro sequence and the 3 dates offer analyses in good agreement with the ${ }^{14} \mathrm{C}$ calibration curve): see Figure 5 . The calculated terminus post quem (last extant ring) is placed 2944-2895 cal BC at 68.2\% probability or 2955-2872 cal BC at 95.4\% probability. We may then estimate the cutting date range, as discussed above, allowing for the average number of sapwood rings in Italian oaks as our best available guide. This approximation gives us a likely approximate human use date for the timber around or after about 2932-2881 cal BC at 68.2\% probability and 2947-2859 cal BC at 95.4\% probability. (Note: when the other subsequent Manerba data are also taken into account [see Figure 6], then the last extant ring is placed slightly later at about 2921-2879 cal BC at 68.2\% probability and 2948-2872 cal BC at 95.4\% probability, and the estimated cutting date range is placed at about 2910-2866 cal BC at 68.2\% probability and 2936-2856 cal BC at 95.4\% probability.)

The dendro wiggle-matched (DWM) date from Timber F is the first of its kind for the Italian Copper Age for a specifically archaeological sample (other wiggle-match work has been employed on dendrochronological timber samples in Italy, such as the Early Neolithic La Marmotta submerged lakeshore site [Kromer 2009:17, Figure 3], the Early Bronze Age GARDA 1 regional oak chronology, and the Early Bronze Age/beginning of the Middle Bronze Age GARDA 3 oak chronology [Martinelli 2007:104, 107-8]). This date provides us with a terminus post quem (TPQ) for the construction and subsequent use of burial chamber 133. (Note that a single conventional measurement [Birm1132: $4420 \pm 90 \mathrm{BP}$ ] previously obtained from structural oak Timber B-not necessarily from outer tree rings - in the same chamber is consistent with the measurements used for the wiggle-matching of Timber F: see Figure 6). Some other ${ }^{14} \mathrm{C}$ dates provide evidence for the subsequent use of the overall burial complex (see Tables 2 and 3; Figure 2) and allow us to better conceive the dating of the construction and subsequent use of the funerary complex as a whole (see Figure 6).

The only other available ${ }^{14} \mathrm{C}$ date relating to Chamber 133 (OxA-4547: $4040 \pm 60 \mathrm{BP}$ ), on shortlived material (charred barley grains [Hordeum sp. L.]), is not related to the primary burial use of the chamber, but instead comes from the later fill of Chamber 133 (i.e. from Context 58), which is linked with the closure process of the chamber itself (and indeed to the initial phase of platform building - in this case the construction of the Southern Platform). This date should be later than the cutting date range. In the Northern Area, we do not have any direct stratigraphic relationships (i.e. direct superimposition) between the 3 dated contexts available (i.e. Contexts 58, 128, and 146; see Table 2); however, based on the apparent construction sequence of the 2 covering platforms (i.e. the Southern Platform being older than the Northern Platform), the relative sequence of the dated cereal samples may likely be reconstructed as follows, though still with some uncertainties:

Phase 1. Later fill of Chamber 133 (Context 58): OxA-4547.

Phase 2. Upper part of the Cremation Pit in the base of the Northern Platform construction (Context 146): OxA-4549.

Phase 3. Context 128 within the thickness of the Northern Platform: OxA-4548.

\footnotetext{
${ }^{1}$ Note: After this paper was submitted, the IntCal09 calibration curve was published (Reimer et al. 2009), but as there has been no change to the tree-ring part of the calibration curve, we have left the citations in this paper as IntCal04 (Reimer et al. 2004).
} 


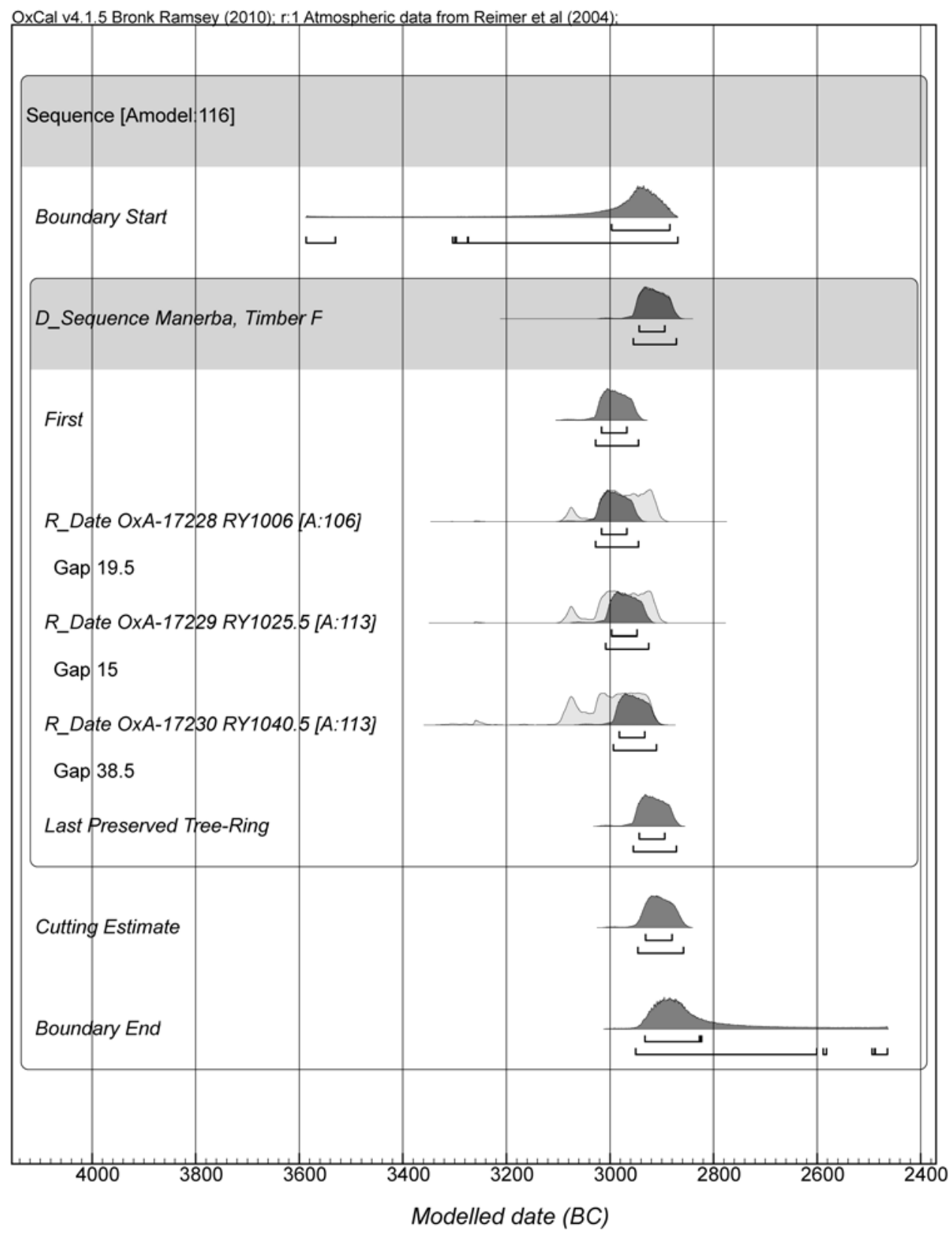

Figure 5 Dendro wiggle-match (DWM) of the 3 Manerba Timber F samples (see Table 1) given the known treering (calendar yr) spacing through to the last extant tree ring (ring 1079_-placed 2944-2895 cal BC at 68.2\% probability and 2955-2872 cal BC at 95.4\% probability), and then an estimation of the likely cutting date range given average sapwood for Italian oak (see text) employing OxCal 4.1.5 (curve resolution =1) (Bronk Ramsey 1995, 2001, 2009, 2010) and IntCal04 (Reimer et al. 2004). The hollow histograms show the calibrated calendar age ranges for the 3 unmodeled ${ }^{14} \mathrm{C}$ dates; the solid histograms show the modeled calendar age ranges applying the Bayesian analysis model described. The $68.2 \%$ and $95.4 \%$ probability ranges for the modeled ranges are indicated below each histogram. (Note: each run of such an OxCal analysis will calculate slightly different probabilities/ ranges for the modeled functions.) 


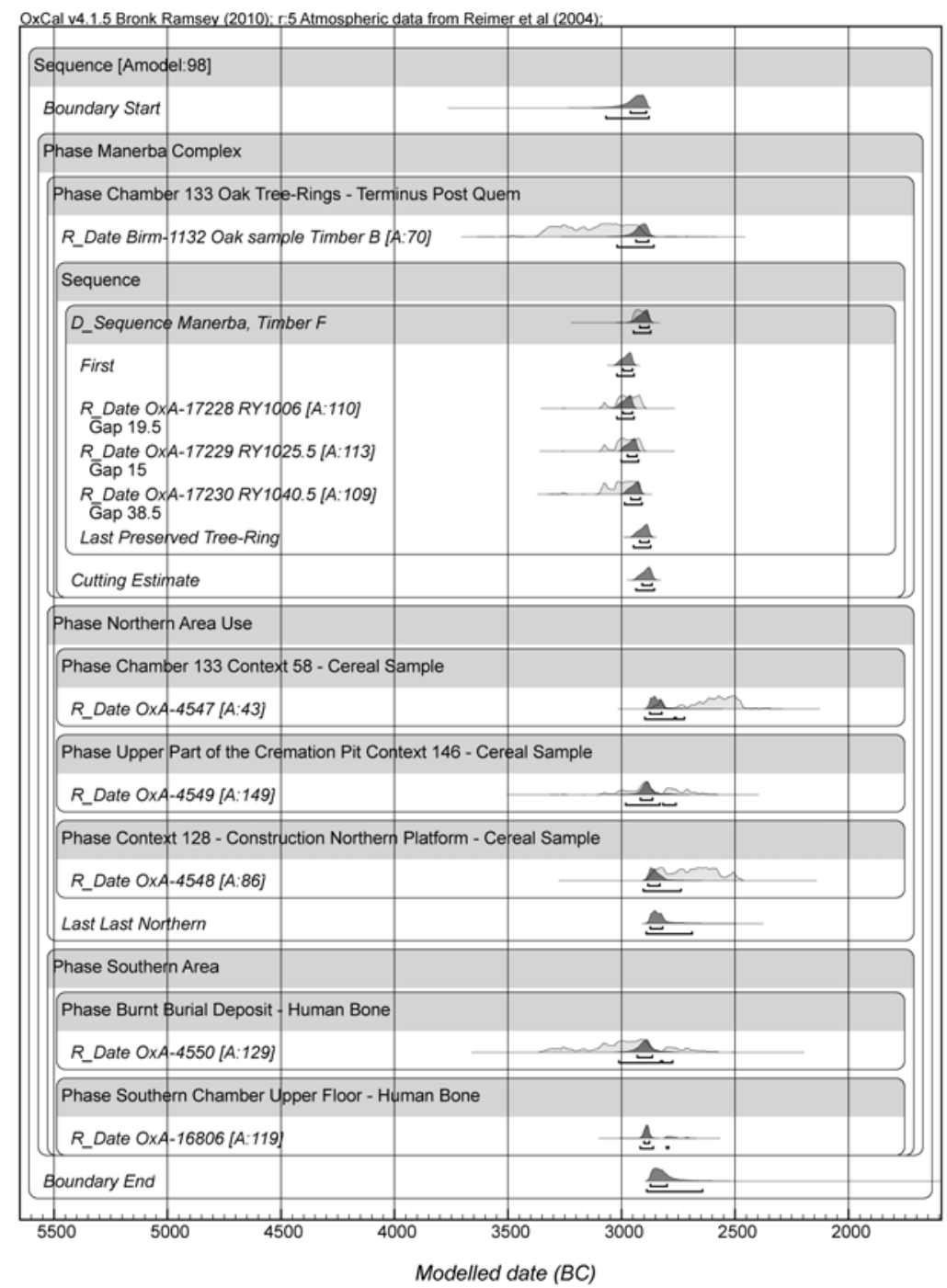

Figure 6 Modeled analysis of the Manerba sequence combining all the data in Tables 1-3 employing OxCal 4.1.5 (curve resolution = 5) (Bronk Ramsey 1995, 2001, 2009, 2010) and IntCal04 (Reimer et al. 2004). (The OxCal file is listed in the Appendix.) The order (oldest to most recent) reads from top to bottom. The oak samples from the construction of the funerary structures offer terminus post quem ranges for the use of the Northern Area of the funerary complex (most closely defined by the cutting/use date for Timber F). The stratigraphic sequencing is not definitive, but the Northern Area contexts are set out in what is believed to be the chronological sequence-although the specific relationships both within each of the overall Northern Area and Southern Area phases are left flexible. The relationship between the Northern and Southern areas is also left flexible as there is no stratigraphic relationship. Nevertheless, the finds of the same pottery types at both areas (e.g. metope decorated bowls and zone-decorated bowls; see Barfield 2007c:195-6, 198-9, Figures 125, 126) would seem to indicate no substantive time difference between the Northern and Southern areas (consistent with the ${ }^{14} \mathrm{C}$ evidence). The samples offer a generally coherent analysis with good overall OxCal agreement indices $\left(A_{\text {model }}=98.1\right.$ and $A_{\text {overall }}=93.8$ ), although OxA-4547 would prefer to date a little later than the other Northern Area samples (contrary to the apparent stratigraphy for the Northern Area), and hence it is a slight outlier (OxCal agreement index value of 43.3 less than the approximate $95 \%$ confidence threshold value of 60), even given the model shown (which does not require it to date earlier than the other 2 phases within the overall Phase "Northern Area Use"). The hollow histograms show the unmodeled calibrated age distributions for the individual samples; solid histograms show the modeled distributions applying the Bayesian model indicated. The $68.2 \%$ and $95.4 \%$ probability ranges for the modeled ranges are indicated below each histogram. 


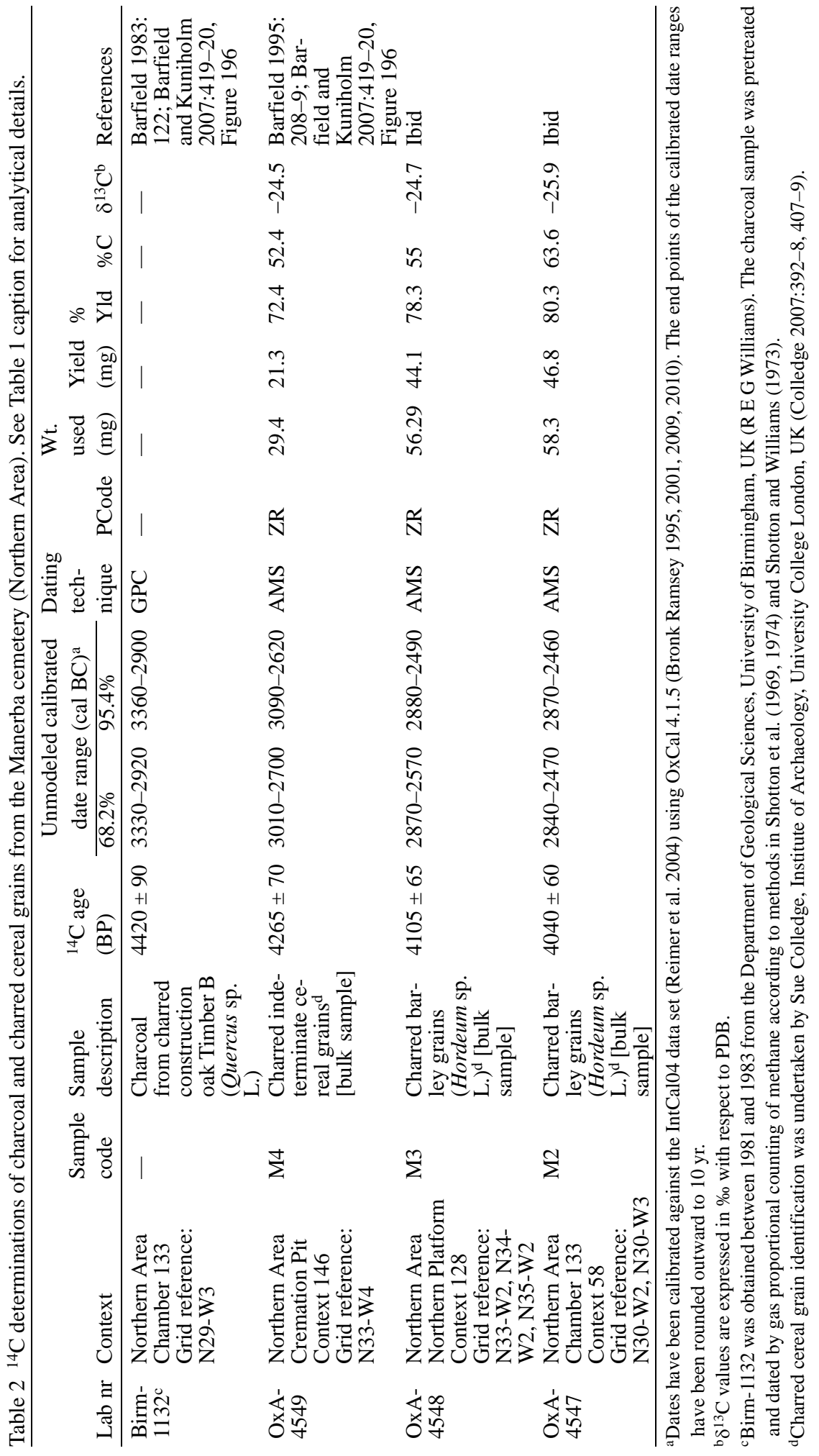




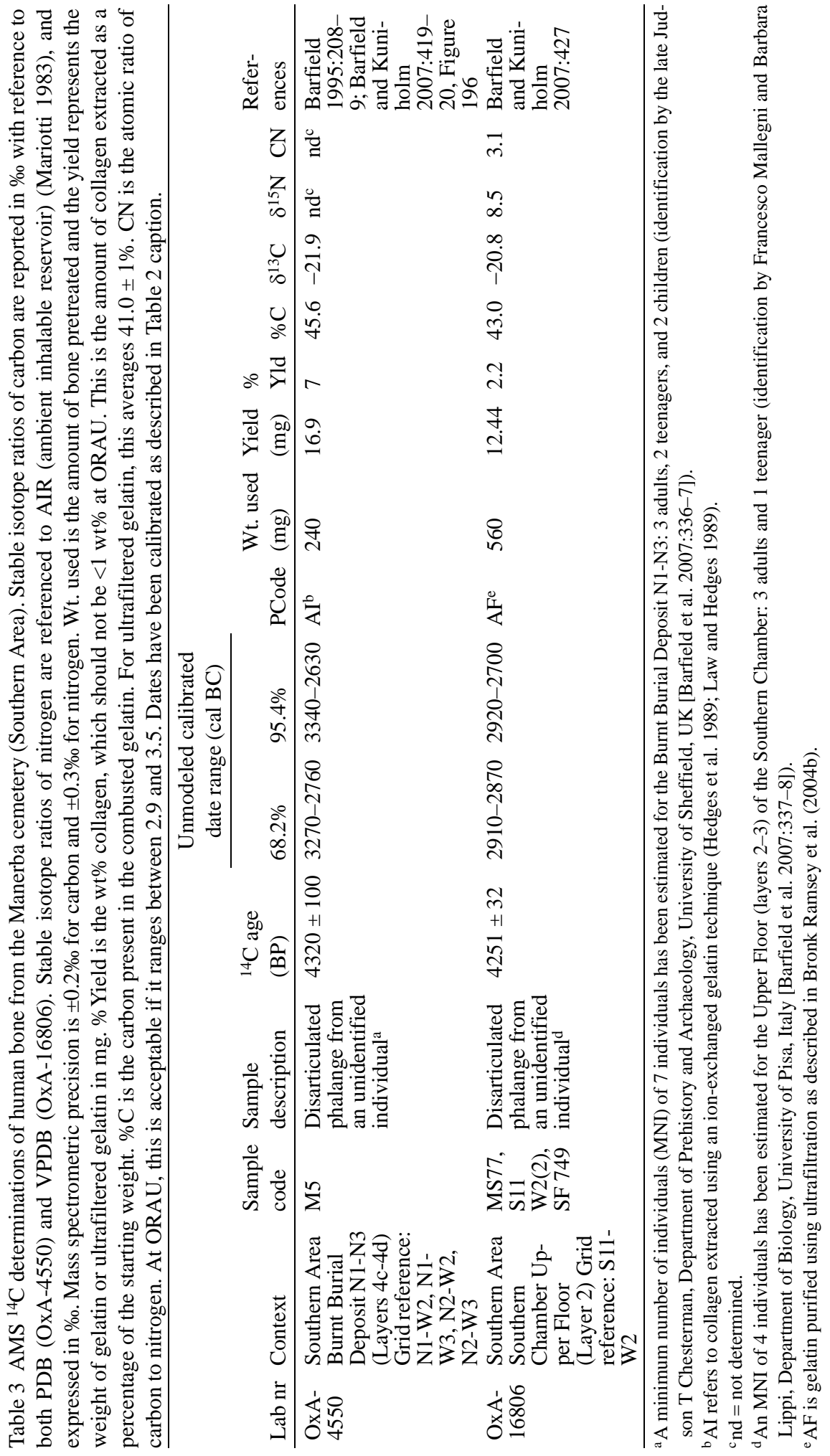


The OxCal model (see Figure 6 and Appendix) treats each of these phases as separate within the overall Northern Area Use phase (Phase "Northern Area Use"). All are placed loosely following the "Cutting Estimate" (since this TPQ defines the start of use of Chamber 133, whereas all the other Northern Area Use dates relate to subsequent activities). In line with the stratigraphic uncertainties, the relationships between the 3 subsequent "phases" (1-3 above) are then left flexible.

It is worth further clarifying something ambiguous: the precise sequence of the construction and use of the 4 Northern Chambers, and indeed the 2 covering platforms, is not entirely straightforward, due to the lack of clear stratigraphic evidence. Nevertheless, as noted above, the Southern Platform - sealing Chambers 132 and 133 - would appear to be older than the Northern Platform —sealing Chambers 134 and 135. Thus Chambers 132 and 133 should be older than Chambers 134 and 135. However, Chamber 133 is not necessarily the earliest chamber built at the site, since Chamber 132 remains undated, and the relation between these 2 chambers is unclear. Nonetheless, taking into account that both Chambers 132 and 133 were of a near identical size and shared the same architectural typology, it is reasonable to maintain that the construction of these 2 chambers most likely occurred within about the same span of time, and thus likely somewhere around the time delineated by the "Cutting Estimate" in Figures 5 and 6. The other Northern Area Use dates come from subsequent activities, after the main burial phase, linked with the closure of the chambers and the subsequent platform construction, and so reasonably are placed as after the "Cutting Estimate." The Southern Area is left flexible in terms of the Northern Area.

OxA-4547 (4040 $\pm 60 \mathrm{BP}$ ) stands out as something of a slight outlier (the OxCal agreement index value in Figure 6 is 43.3-less than the approximate 95\% confidence threshold value of 60), since it is later than the dates obtained on cereal grains collected from both the upper part of the Cremation Pit in the base of the Northern Platform (OxA-4549: $4265 \pm 70$ BP), and Context 128 (OxA-4548: $4105 \pm 65$ BP), an extensive layer contained within the body of the Northern Platform itself. Overall, though, the Northern Area offers a fairly coherent picture, with funerary complex construction around or after the Chamber 133 "Cutting Estimate" of 2910-2866 cal BC (68.2\% probability) followed by later phases of activity placed respectively, 2876-2823 cal BC, 2917-2864 cal BC, and 2884-2832 cal BC at 68.2\% probability: see modeled ages for OxA-4547, -4549, and -4548 in Figure 6.

There is no stratigraphic relationship between the Northern and Southern areas of the Manerba complex, and the ${ }^{14} \mathrm{C}$ evidence thus provides an opportunity to assess the chronological relationships between these 2 distinct areas of the site. The OxCal model (Figure 6 and Appendix) thus places the Southern Area in its own phase ("Southern Area") within the overall phase "Manerba Complex" and leaves the relationship between this Southern Area phase and the Northern Area Use phase flexible. The 2 Southern Area dates (OxA-4550 and -16806) are respectively placed 2931-2865 cal BC and 2901-2878 cal BC at $68.2 \%$ probability.

Thus, contrary to previous suggestions (Barfield 1995:209; Barfield and Kuniholm 2007:422), the (limited) evidence available would seem to show that it is very likely that the burials from the Southern Area were broadly contemporary with (or at least close in date to) the time the Northern Area was also being used. The Southern Area dates, which relate to the burials made here, could be argued to be more or less contemporary with the period from around and after the "Cutting Estimate" through the time of the closure of the Northern Area (i.e. the Northern Area Use dates) - thus the overall timespan when burials were being made in the Northern Area. In particular, the dates from both the Burnt Burial Deposit N1-N3 (OxA-4550: $4320 \pm 100$ BP) and the Upper Floor (layers 2-3) of the Southern Chamber (OxA-16806: $4251 \pm 32$ BP) are statistically indistinguishable from the date available for the above-mentioned Cremation Pit (OxA-4549: $4265 \pm 70$ BP) ( $T^{\prime}=0.4$; $T^{\prime}[5 \%]=6.0 ; d f=2$; Ward and Wilson 1978). 


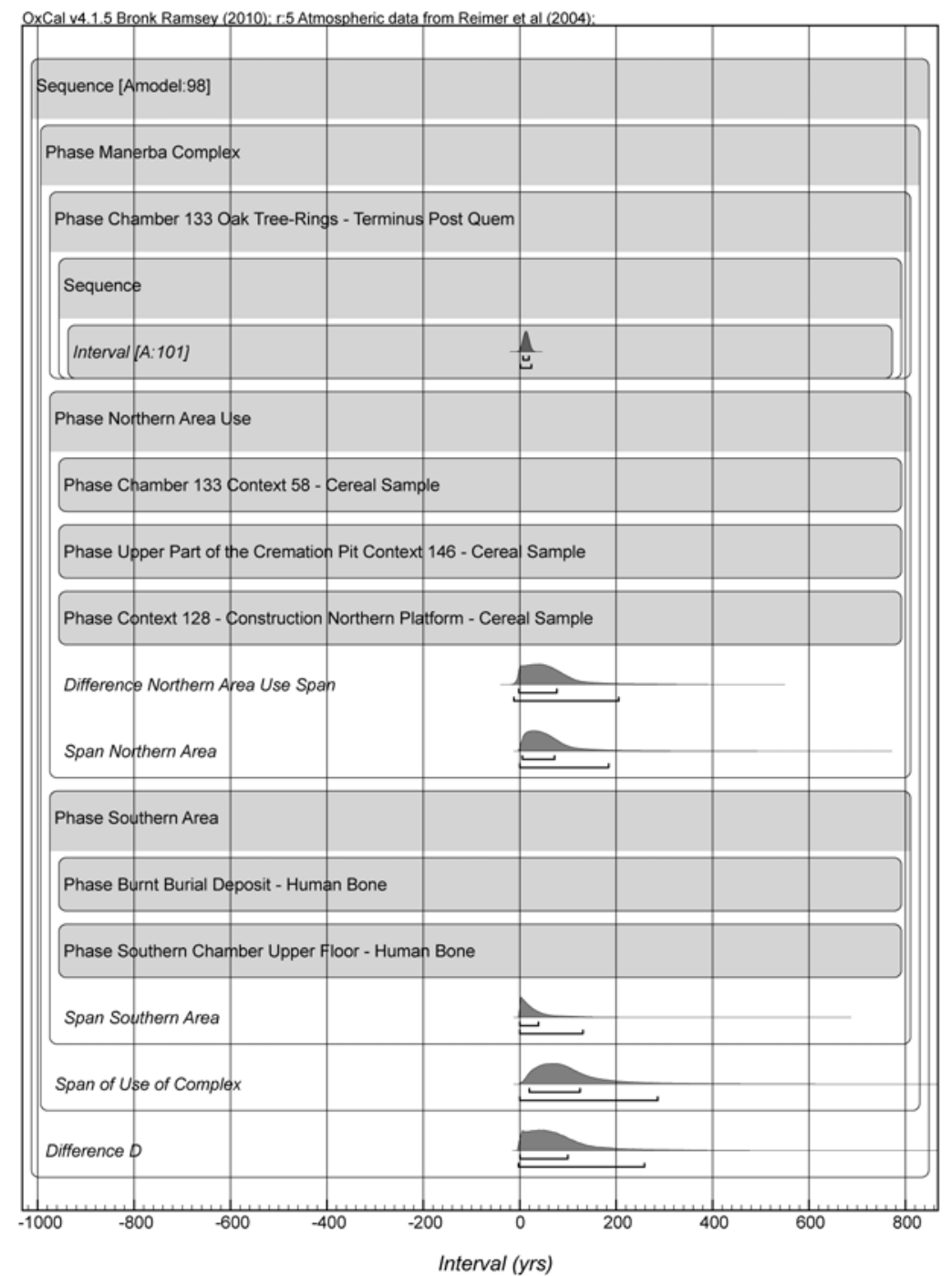

Figure 7 OxCal model for the Manerba funerary complex (see Figure 6 and Appendix) showing: (i) the calculated time spans (calendar yr) of the Difference (time interval) from the end of the Phase "Northern Area Use" to the "Cutting Estimate" for Timber $\mathrm{F}$ (see Figure 6) $=-1$ to $77 \mathrm{yr}$ at $68.2 \%$ probability and -12 to $206 \mathrm{yr}$ at $95.4 \%$ probability, and the Span (time interval) of the phases "Northern Area Use," "Southern Area," and the overall Span "of Use of Complex" (comprising all shorter or short-lived samples from the use, closure, and platform building contexts of the burial complex in Tables 2 and 3). These are: Northern Area Use 6 to 73 yr at 68.2\% probability and 0 to 185 yr at 95.4\% probability; Southern Area 0 to 39 yr at 68.2\% probability and 0 to 131 yr at 95.4\% probability; and Use of Complex 20 to 125 yr at 68.2\% probability and 0 to 287 yr at 95.4\% probability. A subjective inspection of the overall Span "of Use of Complex" histogram (mode of the distribution) suggests the most likely range centers $\sim 60-80 \mathrm{yr}$ (median value is $87 \mathrm{yr}$ ), despite the substantial and long "tail” of larger values (which leads to a mean value of $107 \mathrm{yr}$ with SD of $84 \mathrm{yr}$ ). This might be argued (although we only have a rather small data set and caution is appropriate) to suggest that something around only $100 \mathrm{yr}$ (give or take $50 \mathrm{yr}$ ) of overall use is indicated for the Manerba complex - thus, a relatively short period. (ii) the Difference " $D$ " (calendar yr) in time between the concluding Boundary "End" (2873-2800 cal BC at 68.2\% probability and 2889-2644 cal BC at 95.4\% probability) and the "Cutting Estimate"- thus, the period from the terminus post quem for the construction of the burial complex to a point after its use (on the basis of the ${ }^{14} \mathrm{C}$ dates available) as defined by the Boundary "End": 1 to $100 \mathrm{yr}$ at $68.2 \%$ probability and -2 to 259 yr at $95.4 \%$ probability. 
We may also approximately quantify the likely maximum length of time between the construction of Chamber 133 (approximate cutting date estimate for Timber F) and an age for the end of use of the funerary complex (the Boundary "End") in the analysis shown in Figure 6 using the Difference function in OxCal (labeled "D"): see Figure 7. This calculates an interval range probability of 1 to 100 calendar yr at $68.2 \%$ probability and -2 to 259 yr at $95.4 \%$ probability. This is the likely maximum period of use of the funerary complex; a more likely estimate of the span of time the funerary complex was in use can be determined from the Span function of OxCal applied to the overall Phase "Manerba Complex" in Figure 6 as shown in Figure 7 (Span "of Use of Complex"): 20 to 125 yr at $68.2 \%$ probability and 0 to 287 yr at $95.4 \%$ probability.

The available Manerba ${ }^{14} \mathrm{C}$ dates therefore seem to point to a relatively short period of activity at this funerary complex during the first half of the 3rd millennium cal BC, most likely within its first quarter. This situation stands in contrast with the much wider spread of dates found in the nearby Remedello cemetery—seemingly covering over 900 yr, between 3350 and 2400 cal BC (de Marinis 1997) — which in turn may indicate differences between the sociopolitical or other factors in operation at the 2 locations.

Previously, we suggested a continuity of the use of the Manerba site after about $2500 \mathrm{cal}$ BC because of the presence of unstratified Beaker sherds (e.g. Barfield 1995:209, 1999:58, 2007a:533; Barfield and Kuniholm 2007:422) — the onset of north Italian Beakers being conventionally placed around the mid-3rd millennium cal BC (Barfield 1994:22, Figure 11; Barfield and Kuniholm 2007:426). However, based on the results from this analysis, we must now envisage the possibility of a break between the cemetery use and the Beaker "event." The latter may have just represented veneration of an earlier ancestral site rather than a continuation of the use of the cemetery.

\section{CONCLUSION}

A precise date range has been obtained by ${ }^{14} \mathrm{C}$ dendro wiggle-matching (DWM) for the construction of the wooden (oak) funerary structure in one chamber (133) of the important Manerba funerary complex in northern Italy (Barfield 2007a): the last extant ring dates 2944-2895 cal BC at 68.2\% probability or 2955-2872 cal BC at 95.4\% probability; the estimated cutting date for the timber and thus its human use in the construction of a burial chamber is likely around or not long after 29322881 BC at $68.2 \%$ probability and $2947-2859$ cal BC at $95.4 \%$ probability. Analysis of the other ${ }^{14} \mathrm{C}$ evidence available and relevant to the use of the funerary complex indicates subsequent use likely for about 20 to $125 \mathrm{yr}$ (68.2\% probability) or 0 to $287 \mathrm{yr}$ (95.4\% probability).

\section{ACKNOWLEDGMENTS}

We thank Jennifer Watkins for her work on Timber F, and the staff of the Oxford Radiocarbon Accelerator Unit for their work on the Manerba samples. We also thank Sue Colledge, Barbara Lippi, and Renato Nisbet who provided additional information respectively on the provenience of the ${ }^{14} \mathrm{C}$-dated cereal samples, the human remains, and the identification of the charred construction timbers in Chamber 133. We thank Alex Bayliss, Christopher Bronk Ramsey, and 2 anonymous reviewers for their comments.

\section{REFERENCES}

Barfield LH. 1982. Scavi al Riparo Valtenesi, Sasso di Manerba, 1981. Soprintendenza Archeologica della Lombardia. Notiziario 1981:11-3. In Italian.

Barfield LH. 1983. The Chalcolithic cemetery at Manerba del Garda. Antiquity 57(220):116-23.
Barfield LH. 1985. Burials and boundaries in Chalcolithic Italy. In: Malone C, Stoddart S, editors. Papers in Italian Archaeology IV. The Cambridge Conference. Part II: Prehistory. BAR International Series 244. Oxford: British Archaeological Reports. p 152-76. 
Barfield LH. 1987. Chalcolithic burial ritual in Northern Italy-problems of social interpretation. In: Bergonzi G, Bietti Sestieri AM, Cazzella A, editors. Prospettive storico-antropologiche in archeologia preistorica. Atti del Convegno (Rome, 4-6 January 1986). Quaderni di Dialoghi di Archeologia 3. Rome: Edizioni Quasar. p 241-8.

Barfield LH. 1994. The Iceman reviewed. Antiquity 68(258):10-26.

Barfield LH. 1995. Riparo Valtenesi, Manerba del Garda. In: Hedges REM, Housley RA, Bronk Ramsey C, van Klinken GJ. Radiocarbon dates from the Oxford AMS system: Archaeometry datelist 19. Archaeometry 37(1):208-9.

Barfield LH. 1998. L'Italie septentrionale-Grottes et abris funéraires. Autres types de sepultures collectives. In: Guilaine J, editor. Atlas du Néolithique européen. 2A: L'Europe occidentale. Etudes et Recherches Archéologiques de l'Université de Liège (ERAUL) 46. Liège: Université de Liège. Service de Préhistoire. p 266-9. In French.

Barfield LH. 1999. Copper age pottery from the Riparo Valtenesi, Manerba del Garda. In: Preistoria e Protostoria del Trentino-Alto Adige/Südtirol. XXXIII Riunione Scientifica dell'Istituto Italiano di Preistoria e Protostoria in ricordo di Bernardino Bagolini (Trento, 21-24 October 1997). Preistoria Alpina 35:55-65.

Barfield LH. 2004. The use of wood in the Copper Age funerary monuments at Manerba del Garda and its use in contemporary ritual monuments. In: Casini S, Fossati AE, editors. Le pietre degli dei. Statue-stele dell'età del Rame in Europa. Lo stato della ricerca. Atti del Congresso Internazionale (Brescia, 16-18 September 2004). Notizie Archeologiche Bergomensi 12:39-48.

Barfield LH, editor. 2007a. Excavations in the Riparo Valtenesi, Manerba, 1976-1994. Florence: Istituto Italiano di Preistoria e Protostoria. 593 p.

Barfield LH. 2007b. The Northern Area and the Northern Chambers N27 to N38. In: Barfield LH, editor. Excavations in the Riparo Valtenesi, Manerba, 1976-1994. Florence: Istituto Italiano di Preistoria e Protostoria. p 44-122.

Barfield LH. 2007c. Copper Age pottery. In: Barfield LH, editor. Excavations in the Riparo Valtenesi, Manerba, 1976-1994. Florence: Istituto Italiano di Preistoria e Protostoria. p 159-216.

Barfield LH. 2007d. Discussion of the Copper Age cemetery. In: Barfield LH, editor. Excavations in the Riparo Valtenesi, Manerba, 1976-1994. Florence: Istituto Italiano di Preistoria e Protostoria. p 431-59.

Barfield LH, Kuniholm PI. 2007. Radiocarbon dating and the absolute chronology of the cemetery. In: Barfield LH, editor. Excavations in the Riparo Valtenesi, Manerba, 1976-1994. Florence: Istituto Italiano di Preistoria e Protostoria. p 419-27.

Barfield LH, Mallegni F, Lippi B, Chesterman J. 2007.
Human remains. In: Barfield LH, editor. Excavations in the Riparo Valtenesi, Manerba, 1976-1994. Florence: Istituto Italiano di Preistoria e Protostoria. p 335-71.

Baroni C. 2007. Geology and geomorphology of Lake Garda and the Manerba promontory. In: Barfield LH, editor. Excavations in the Riparo Valtenesi, Manerba, 1976-1994. Florence: Istituto Italiano di Preistoria e Protostoria. p 501-17.

Bayliss A, Tyers I. 2004. Interpreting radiocarbon dates using evidence from tree rings. Radiocarbon 46(2): 957-64.

Brock F, Higham T, Ditchfield P, Bronk Ramsey C. 2010. Current pretreatment methods for AMS radiocarbon dating at the Oxford Radiocarbon Accelerator Unit (ORAU). Radiocarbon 52(1):103-12.

Bronk Ramsey C. 1995. Radiocarbon calibration and analysis of stratigraphy: the OxCal program. Radiocarbon 37(2):425-30.

Bronk Ramsey C. 2001. Development of the radiocarbon calibration program. Radiocarbon 43(2A):355-63.

Bronk Ramsey C. 2009. Bayesian analysis of radiocarbon dates. Radiocarbon 51(1):337-60.

Bronk Ramsey C. 2010. OxCal 4.1 [software and online manual]. Oxford Radiocarbon Accelerator Unit. URL: https://c14.arch.ox.ac.uk/oxcal/OxCal.html.

Bronk Ramsey C, Higham T, Leach P. 2004a. Towards high-precision AMS: progress and limitations. Radiocarbon 46(1):17-24.

Bronk Ramsey C, Higham T, Bowles A, Hedges R. 2004b. Improvements to the pretreatment of bone at Oxford. Radiocarbon 46(1):155-63.

Bronk Ramsey C, van der Plicht J, Weninger B. 2001. 'Wiggle matching' radiocarbon dates. Radiocarbon 43(2A):381-9.

Colledge S. 2007. The Copper Age carbonised plant remains. In: Barfield LH, editor. Excavations in the Riparo Valtenesi, Manerba, 1976-1994. Florence: Istituto Italiano di Preistoria e Protostoria. p 391-413.

Coplen TB. 1994. Reporting of stable hydrogen, carbon, and oxygen isotopic abundances. Pure and Applied Chemistry 66(2):273-6.

Dee M, Bronk Ramsey C. 2000. Refinement of graphite target production at ORAU. Nuclear Instruments and Methods in Physics Research B 172(1-4):449-53.

de Marinis RC. 1997. The eneolithic cemetery of Remedello Sotto (BS) and the relative and absolute chronology of the Copper Age in Northern Italy. Notizie Archeologiche Bergomensi 5:33-51.

Galimberti M, Bronk Ramsey C, Manning SW. 2004. Wiggle-match dating of tree-ring sequences. Radiocarbon 46(2):917-24.

Haneca K, Čufar K, Beeckman H. 2009. Oaks, tree-rings and wooden cultural heritage: a review of the main characteristics and applications of oak dendrochronology in Europe. Journal of Archaeological Science 36(1):1-11. 
Hedges REM, Law IA, Bronk CR, Housley RA. 1989. The Oxford accelerator mass spectrometry facility: technical developments in routine dating. Archaeometry 31(2):99-113.

Kromer B. 2009. Radiocarbon and dendrochronology. Dendrochronologia 27(1):15-9.

Law IA, Hedges REM. 1989. A semi-automated bone pretreatment system and the pretreatment of older and contaminated samples. Radiocarbon 31(3):247-53.

Mariotti A. 1983. Atmospheric nitrogen is a reliable standard for natural ${ }^{15} \mathrm{~N}$ abundance measurements. Nature 303(5919):685-7.

Martinelli N. 2007. Dendrocronologia delle palafitte dell'area gardesana: situazione delle ricerche e prospettive. In: Morandini F, Volonté M, editors. Contributi di archeologia in memoria di Mario Mirabella Roberti. Atti del XVI Convegno Archeologico Benacense (Cavriana, 15-16 October 2005). Annali Benacensi XIII-XIV:103-20. In Italian.

Miles DH. 2005. New developments in the interpretation of dendrochronology as applied to oak building timbers [unpublished $\mathrm{PhD}$ dissertation]. University of Oxford.

Nisbet R, Barfield LH. 2007. Charcoals, grass micro-remains and thread analysis. In: Barfield LH, editor. Excavations in the Riparo Valtenesi, Manerba, 19761994. Florence: Istituto Italiano di Preistoria e Protostoria. p 414-8.

Reimer PJ, Baillie MGL, Bard E, Bayliss A, Beck JW, Bertrand CJH, Blackwell PG, Buck CE, Burr GS, Cut- ler KB, Damon PE, Edwards RL, Fairbanks RG, Friedrich M, Guilderson TP, Hogg AG, Hughen KA, Kromer B, McCormac G, Manning S, Bronk Ramsey C, Reimer RW, Remmele S, Southon JR, Stuiver M, Talamo S, Taylor FW, van der Plicht J, Weyhenmeyer CE. 2004. IntCal04 terrestrial radiocarbon age calibration, 0-26 cal kyr BP. Radiocarbon 46(3):1029-58.

Reimer PJ, Baillie MGL, Bard E, Bayliss A, Beck JW, Blackwell PG, Bronk Ramsey C, Buck CE, Burr GS, Edwards RL, Friedrich M, Grootes PM, Guilderson TP, Hajdas I, Heaton TJ, Hogg AG, Hughen KA, Kaiser KF, Kromer B, McCormac FG, Manning SW, Reimer RW, Richards DA, Southon JR, Talamo S, Turney CSM, van der Plicht J, Weyhenmeyer CE. 2009. IntCal09 and Marine09 radiocarbon age calibration curves, 0-50,000 years cal BP. Radiocarbon 51(4): 1111-50.

Shotton FW, Williams REG. 1973. Birmingham University radiocarbon dates VII. Radiocarbon 15(3):45168.

Shotton FW, Blundell DJ, Williams REG. 1969. Birmingham University radiocarbon dates III. Radiocarbon 11(2):263-70.

Shotton FW, Williams REG, Johnson AS. 1974. Birmingham University radiocarbon dates VIII. Radiocarbon 16(3):285-303.

Ward GK, Wilson SR. 1978. Procedures for comparing and combining radiocarbon age determinations: a critique. Archaeometry 20(1):19-31.

\section{APPENDIX: OXCAL RUN FILE FOR FIGURES 6-7}

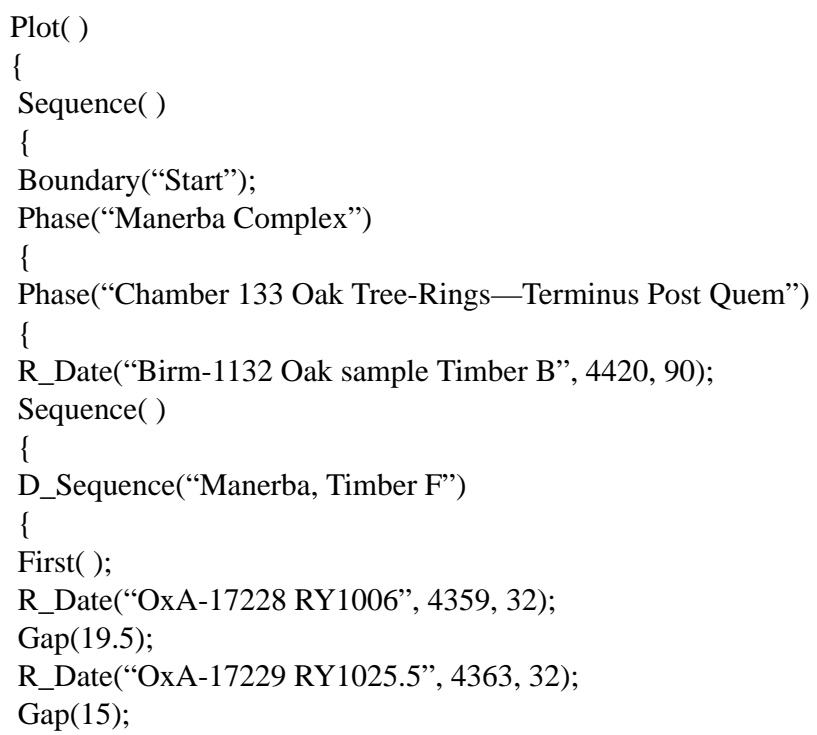


R_Date(“OxA-17230 RY1040.5”, 4385, 33);

Gap(38.5);

Date(“Last Preserved Tree-Ring”);

\};

Interval(N(13.23,6.06));

Date(“Cutting Estimate”);

;

\};

Phase("Northern Area Use”)

\{

Phase(“Chamber 133 Context 58-Cereal Sample”)

\{

R_Date(“OxA-4547”, 4040, 60);

\};

Phase("Upper Part of the Cremation Pit Context 146-Cereal Sample”)

\{

R_Date(“OxA-4549”, 4265, 70);

\};

Phase(“Context 128 —Construction Northern Platform—Cereal Sample”)

\{

R_Date(“OxA-4548”, 4105, 65);

\};

Last(“Last Northern”);

Difference(“Northern Area Use Span”, “Last Northern”, “Cutting Estimate”);

Span(“Northern Area”);

;

Phase(“Southern Area”)

\{

Phase("Burnt Burial Deposit-Human Bone”)

\{

R_Date(“OxA-4550”, 4320, 100);

\} ;

Phase(“Southern Chamber Upper Floor-Human Bone”)

\{

R_Date(“OxA-16806”, 4251, 32);

\};

Span(“Southern Area”);

;

Span(“of Use of Complex”);

\};

Boundary(“End”);

Difference(“D”, “End”, “Cutting Estimate”);

;

; 